\title{
TRANSAKSI MATA UANG DALAM PANDANGAN ISLAM
}

\author{
Zainal Abidin
}

(D osen jurusan Syari'ah STA IN Pamekasan, JI. Raya Panglegur km. 04 Pamekasan, email:sinal1000@yahoo.com)

\begin{abstract}
A bstract:
The trading of money in modern era is very important to control and balance of global economic. Over this system, the procces of global trading are exist and more easier. Baut in other side according to Islamic concept the trading of maney have to follow the patterns are recommaded. This artide want to explain about the pattern about Islamic concept in the money trading. The minimal target is may be can give inspiration and spirit in money trading. The target is not impossible if we mant to do effort to do something especially in the system of transaction, the statement of transaction, etc. To change the all of methode in the modern/ commercial system in the money trading is imposible but create the new system mhich the convergent between Islamic and commercial system in trading of money is impoosible and be the target.
\end{abstract}

\section{Key Words:}

jual beli, uang, gharâr, maysir, ribâ dan juhala, dan hukum Islam

\section{Pendahuluan}

Islam sebagai agama yang rahmat li al-'âlamîn tidak hanya memberikan perhatian kepada masalah 'ubudiyah, tetapi juga memberikan perhatian yang tinggi terhadap masalah mu'âmalah. Banyak ayat al-Qur'ân yang menjelaskan, bahkan memberikan nilai yang sangat tinggi dan positif secara hukum terhadap bidang tersebut, khususnya yang berkaitan dengan aktivitas ekonomi. Hal ini dikarenakan hasil aktivitas ekonomi dipandang dalam ajaran Islâm mempunyai kaitan erat dengan rahmat Allâh SWT yang dilimpahkan kepada umat manusia. 
Sesuai dengan perkembangan zaman, kegiatan ekonomi dari masa ke masa juga mengalami banyak perubahan yang dulunya tidak ada, sekarang ada atau sebaliknya. Pada mulanya, barter merupakan sistem perdagangan yang diberlakukan sebelum diciptakan uang sebagai alat tukar. Perekonomian sistem barter adalah suatu kancah perekonomian yang dalam sistem transaksinya barang saling dipertukarkan. Setiap barang pada dasarnya berfungsi sebagai "uang". Ketika pelaku ekonomi telah menemukan uang sebagai alat transaksi, maka uang telah disepakati sebagai alat tukar dalam dunia perekonomian. Menurut Darmawan, uang sebagai alat tukar itu harus terkandung sifat-sifat, seperti harus dikenal, disenangi oleh umum, mudah diangkut, mudah dibagi-bagi tanpa berkurang nilainya, homogen dan tidak mudah rusak. ${ }^{1}$

Uang memiliki berbagai fungsi yang berbeda, seperti sebagai alat tukar nilai, media pertukaran, nilai simpanan dan standar pembayaran yang tertunda. Dalam pandangan pada ahli ekonomi, fungsi uang sebagai alat pertukaran merupakan yang paling penting. Geoffrey Crowther berpendapat bahwa uang harus difungsikan sebagai alat pengukur nilai, medium pertukaran dan simpanan alat pengukur nilai, medium pertukaran dan simpanan kekayaan. Salah satu dari tiga fungsi tersebut, fungsi yang kedua paling penting. Day dalam bukunya The Economics of M oney selain menekankan fungsi yang sama dengan Crowther, ia menambah bahwa salah satu fungsi uang adalah untuk menetapkan sejumlah besar transaksi antara individu-individu dan organisasi yang berbeda dalam perekonomian modern.2

Manan, salah seorang ekonom Muslim, mengatakan bahwa Islam mengakui fungsi uang sebagai alat tukar, bukan suatu komoditi. Diterimanya fungsi ini dengan maksud melenyapkan adanya ketidakadilan, ketidakjujuran, dan pengisapan dalam ekonomi tukar menukar (barter) karena ketidakjujuran ini digolongkan sebagai ribâ al-fadhl yang dilarang agama. Karena itu,

1 Indra Darmawan, Pengantar U ang dan Perbankan, cet. 1. Jakarta: Rineka Cipta, 1992), hlm. 6

2 A.A. Islahi, Konsepsi Ekonomi Ibnu Taimiyah, terj. Anshari Thayib (Surabaya: Bina Ilmu, 1997), hlm. 174-175. 
dalam Islam, menurut Mannan, uang itu sendiri tidak menghasilkan sesuatu apapun. ${ }^{3}$

Saat ini terdapat berbagai bentuk transaksi ekonomi kentemporer, seperti perdagangan mata uang. Dalam kaitan ini, bagaimana figh mu'âmalah menjawab berbagai persoalan tentang bentuk-bentuk transaksi ekonomi kontemporer saat ini, seperti halnya perdagangan mata uang yang pembahasannya dalam kitab-kitab fiqih klasik masih terlalu global. Untuk sampai pada pada pemahaman tersebut, perlulah dikemukakan pandangan hukum Islam terhadap perdagangan mata uang, yang status hukumnya masih dalam keraguan dari segi hukum Islam. Mungkin perdagangan ini tidak akan menjadi persoalan, apabila dalam prakteknya terkandung i'tikad baik agar dalam pelaksanaannya tidak merugikan kedua belah pihak.

\section{Fungsi dan Peranan Uang}

Ada beberapa fungsi mata uang yang amat penting yaitu:4 Pertama, alat tukar menukar. Fungsi uang sebagai alat tukar menukar didasarkan pada kebutuhan manusia yang mempunyai barang dan kebutuhan manusia yang tidak mempunyai barang, di mana uang adalah sebagai perantara di masyarakat. Dengan uang tersebut seseorang bisa memiliki atau mempunyai barang dan orang yang memiliki barang bisa menerima uang sebagai harga dari barang tersebut. Kedua, satuan hitung. Yang dimaksudkan sebagai satuan hitung adalah uang sebagai alat yang digunakan untuk menunjukkan nilai barang dan jasa yang diperjualbelikan di pasar dan besarnya kekayaan yang bisa dihitung berdasarkan penentuan harga dari barang tersebut. Ketiga, penimbun kekayaan. Fungsi yang ketiga yaitu uang sebagai alat penimbun kekayaan akan bisa mempengaruhi jumlah uang kas yang ada pada masyarakat yang mempunyai uang bisa menggunakan uang tersebut untuk dibelanjakan, tapi juga bisa disimpan untuk keperluan yang lain di kemudian hari. Keempat, standar pencicilan utang. Uang juga berfungsi sebagai standar untuk melakukan pembayaran di kemudian hari, pembayaran berjangka

3 M. A bdul Manan, Teori dan Praktek Ekonomi Islam, terj. M. Nastangin (Yogyakarta: PT. Dana Bhakti Wakaf, 1995), hlm. 162.

4 Muchdarsyah Sinungan, U ang dan Bank, cet. ke-3 (Jakarta: Rineka Cipta, 1991), hlm. 6-9. 
atau pencicilan utang. Penggunaan uang sebagai standar pencicilan utang erat berkaitan dan bersamaan waktunya dengan penerimaan masyarakat sebagai alat tukar ataupun alat satuan hitung, oleh karena kegiatan utang piutang adalah berkaitan dengan uang atau merupakan suatu gejala yang umum dalam dunia perdagangan dan perekonomian masyarakat.

Ibn Taymiyah mengatakan bahwa fungsi uang paling utama adalah sebagai alat ukur nilai dan sebagai alat pertukaran. Ibnu Taimiyah menyebutkan bahwa athman (tunggal: thaman) adalah harga atau sesuatu yang dibayarkan sebagai pengganti harga, misalnya uang, dimaksudkan sebagai alat ukur nilai (mi'yâr al-amwâl), melalui uang itu nilai dari sejumlah benda (maqâdir al-amwâl) akan diketahui, dan mereka tidak menggunakannya untuk diri sendiri atau dikonsumsi. 5

Dengan pernyataan itu jelaslah fungsi esensial dari uang adalah untuk mengukur nilai, dibayarkan sebagai alat ukur bendabenda. Ibnu al-Qayyim, murid I bn Taymiyah juga mengatakan fakta yang sama dengan lebih jelas mengatakan bahwa uang atau keping uang tidak dimaksudkan untuk benda itu sendiri, tetapi dimaksudkan untuk memperoleh barang-barang dan ini berarti berfungsi sebagai alat tukar saja. ${ }^{6}$ Pandangan ini sungguh sangat dekat dengan pemikiran ahli yang muncul lebih dari 600 tahun kemudian, seperti dimuat dalam an out line of money yang dikutip oleh Islah bahwa karakteristik esensial dari uang, yang ditetapkan berbeda dari substansinya yang lain, tidak dimaksudkan untuk tujuan barang itu sendiri, tetapi dengan sepenuhnya ditujukan sebagai medium atau sebagai alat mekanisme dari sebuah pertukaran. ${ }^{7}$

Pendapat lain mengenai uang juga dikemukakan oleh Imam al-Ghazâlî bahwa uang tidak dibutuhkan untuk uang itu sendiri. Uang diciptakan untuk melancarkan pertukaran dan menetapkan nilai yang wajar dari pertukaran tersebut. Al-Ghazâlî lebih lanjut mengibaratkan uang bagaikan cermin yang tidak mempunyai warna,

5 Islahi, Konsepsi Ekonomi, hlm. 175.

6 lbid.

7 lbid. 
namun dapat merefleksikan semua warna. ${ }^{8}$ Hanya tidak mempunyai harga, namun merefleksikan harga semua barang, atau dalam ekonomi klasik dikatakan uang tidak memberikan kegunaan secara langsung (direct utility function). Al-Ghazâlî memperbolehkan beredarnya uang yang sama sekali tidak mengandung emas dan perak, asal pemerintah menyatakannya sebagai alat bayar resmi.9

Dari berbagai pendapat itu dapat disimpulkan bahwa fungsi utama uang adalah sebagai alat tukar, maka jika fungsi uang bergeser menjadi komoditas yang diperdagangkan akan menimbulkan kondisi yang membahayakan perekonomian. Ibn Taymiyah berdasarkan alasan itu sangat menentang perdagangan uang, yang artinya menjadikan uang sebagai komoditas yang diperdagangkan. Walaupun demikian, seandainya terjadi barter atau pertukaran uang dengan uang, maka seharusnya pertukaran itu dilakukan secara simultan (taqâbud) dan tidak ada penundaan (hulul), sehingga seseorang akan dapat memenuhi kebutuhannya. ${ }^{10}$

\section{Transaksi Jual Beli Mata Uang}

Meskipun transaksi pertukaran bermacam-macam dan banyak ragamnya, namun transaksi tersebut sebenarnya tidak lepas dari jual beli uang dengan uang lain yang sejenisnya, serta jual beli uang dengan uang lain yang berbeda jenisnya. Transaksi tersebut ada kalanya antara barang yang sama-sama ada, atau sama-sama berupa tanggungan, dan secara mutlak tidak terjadi antara barang yang ada dengan tanggungan. A pabila aktivitas pertukaran tersebut sempurna, kemudian salah seorang di antara mereka ingin menarik kembali, maka tindakan semacam ini tidak diperbolehkan, bila akad dan penyerahannya sudah sempurna. Kecuali kalau di sana terjadi penipuan yang keji atau cacat, maka boleh.

Apabila salah satu pihak dari pembeli atau penjual tersebut menemukan cacat pada barang yang dibeli, misalnya si pembeli atau penjual tertipu. Semisal penjual atau pembeli menemukan perak tersebut berupa tembaga, atau peraknya kusam, maka boleh memilih

${ }^{8}$ Adiwarna A Karim, Ekonomi Islam Suatu Kajian Kontemporer, cet. ke-1 Jakarta: Gema Insani Press, 2001), hlm. 53

9 lbid., hlm. 54.

10 Islahi, Konsepsi Ekonomi, hlm. 176. 
antara mengembalikan atau menerimanya, bila waktunya sudah berubah, namun harga barang yang ditukarkan masih sama. Artinya, mengembalikannya boleh, apabila nilai uang yang diperolehnya belum menyusut dari nilai pada saat masing-masing saling melakukan pertukaran. Namun bila menerimanya, maka jual beli tersebut boleh. Sebaliknya, bila mengembalikannya, maka berarti jual belinya telah rusak.

Apabila seseorang mempunyai tanggungan hutang dengan tempo (kredit), lalu dibilang kepada kreditornya, "serahkan dari yang sebagiannya, dan kamu boleh menyegerakan sisanya." Maka cara semacam ini tidak boleh, sebab cara semacam ini merupakan jual beli antara pembayaran yang disegerakan dengan pembayaran yang ditunda (kredit) dengan tidak disertai kesepadanan. Di samping itu, seakanakan orang tersebut menjual hutangnya kepada rekannya dengan nilai yang lebih rendah daripada hutangnya, ketika barangnya ada, maka berlakulah praktek saling melebihkan, sehingga terjadilah ribâ. Begitu pula bila kreditor tersebut menambahkan nilainya, seperti dikatakan kepada orang yang berhutang tadi: "Engkau ku beri 10 dirham dan segera kembalikan hutangmu". Sebab, ada praktik yang saling melebihkan, sehingga terjadi ribâ.11 Rasulullah SA W bersabda:

$$
\begin{aligned}
& \text { الذهب بالذهب والفضة بالفضة والبر بالبر والشعير بالشعير والتمر بالتمر والملح بالملح مثلا }
\end{aligned}
$$

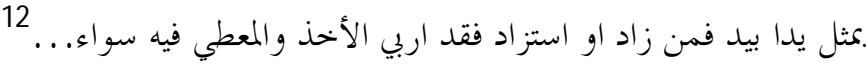

Artinya: Emas dengan emas, perak dengan perak, anggur dengan anggur, gandum dengan gandum, kurma dengan kurma, garam dengan garam harus sama dan diserah terimakan secara langsung (memakai tangank/kontan). Barang siapa menambahi atau memberi tambahan maka sungguh-sungguh sama-sama riba orang yang mengambil dan memberinya.

A pabila ada seseorang yang berada dalam tanggungan orang lain mempunyai emas, sedangkan ada orang lain - dalam tanggungan orang yang pertama tadi- mempunyai perak, lalu masing-masing

11 Taqiyuddin An Nabhani, M embangun Sistem E konomi A Iternatif Perspektif Islam, terj. Maghruf Wachid (Surabaya: Risalah Gusti, 1996), hlm. 291-293.

12 I mâm Muslim, Shahîh M uslim, Jilid I (ttp.: al-Qana‘ah, t.t.), hlm. 692. 
melakukan pertukaran dengan barang yang menjadi tanggungan, misalnya dibayarkan emas yang ada dalam tanggungannya dengan harta yang ada pada dirinya karena hutang dalam bentuk perak, maka pertukaran semacam ini boleh. Sebab tanggungan yang ada, sama seperti barang yang ada. A pabila seseorang membeli barang dengan emas, lalu penjualnya menyerahkan harganya dalam bentuk perak, maka hukumnya mubah. Sebab, diperbolehkan menutup salah satu di antara dua uang dengan yang lain, praktek tersebut merupakan pertukaran barang dengan tanggungan.13

Para fuqahâ' sependapat dan menyatakan bahwa suatu jual beli itu sah apabila cukup syarat-syaratnya. Implikasinya, pada jual beli mata uang sebagai objek jual beli adalah sah menurut syara. Tetapi sebagian ulamâ' seperti Ibn Taymiyah, al-Ghazâlî dan Sura'i, berpendapat bahwa uang tetap berfungsi sesuai dengan hakikatnya yaitu sebagai alat pengukur nilai dan tidak boleh menjadi komoditas yang diperjualbelikan. A pabila ditelusuri lebih jauh, sesungguhnya mata uang yang beredar di dunia saat ini merupakan pengejawantahan dari suatu alat ukur nilai barang (aset) dan mewakili sejumlah barang untuk dapat dipertukaran dengan barang yang lain. A pabila dilihat dari proses evolusinya, pada awalnya uang itu berupa komoditas yang dipertukarkan secara barter (sharf). Dengan demikian secara historis uang juga memiliki posisi sebagai komoditas, atau dengan lain mewakili nilai suatu komoditi.

Selanjutnya harga (kurs) mata uang ditentukan sesuai dengan kesepakatan kedua belah pihak dan pada umumnya terbentuk berdasarkan kekuatan pasar. Menurut ketentuan syara' yang terpenting dari sebuah transaksi adalah adanya kerelaan dan kesepakatan dari kedua belah pihak baik dalam masalah harga maupun objek jual belinya, dan tidak ada unsur gharâr yang dapat merugikan salah satu pihak dikemudian hari, Seperti ditentukan dalam hadits:

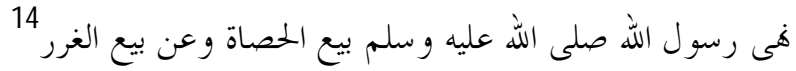
Artinya: "sesungguhnya jual beli itu harus berdasarkan saling rela (ridha). R asullah melarang jual beli yang terpaksa dan menipu".

13 N abhani, M embangun Sistem, hlm. 294.

14 Muslim, Shahîh M uslim, Jilid I, hlm. 658 
Dengan demikian penetapan harga dalam pasar mata uang tidak melanggar. Prinsip-prinsip yang telah ditetapkan oleh syara' dan tujuan utamanya adalah untuk menghindari kezaliman.

\section{Jual Beli Mata Uang dalam Islam}

Jual beli mata uang dalam kajian fiqih klasik dikenal dengan akad sharf, yang berarti penambahan, penukaran, penghindaran atau transaksi jual beli. Ia juga dimaknai sebagai transaksi jual beli mata uang (valuta asing), baik sejenis maupun tidak. ${ }^{15}$

Dalam Ensiklopedi figh Umar bin Khaththâb ra disebutkan bahwa sharf:

$$
\text { الصر ف هو البيع اذا كان كل من عو صية من جنس النا ثمان } 16
$$

Artinya: "Sharf adalah memperjualbelikan uang dengan uang yang sejenis maupun yang tidak sejenis". ${ }^{17}$

Sedangkan ulamâ' figh mendefinisikan sharf dengan memperjualbelikan uang dengan uang yang sejenis maupun yang tidak sejenis. ${ }^{18}$

A ktivitas jual beli mata uang harus terbebas dari unsur hal-hal berikut, yaitu: Pertama, ribâ. Untuk menganalisis ada atau tidaknya unsur ribâ dalam jual beli mata uang, maka hal pertama yang harus dipahami adalah ketentuan syarî'ah tentang ribâ berdasarkan hadîts Nabi SA W yang menjelaskan tentang ribâ al-fadhl, yaitu:

$$
\begin{aligned}
& \text { الذ هب بالذهب, و الفضة بالفضة, والبر بالبر, والشعير بالشعير, والتمر بالتمر, } \\
& \text { والملح بالملح, مثلا بمثل, سواء بسواء, يدا بيد, فاءذا اختلفت هذه الاصناف فبيعوا } \\
& 19
\end{aligned}
$$

Artinya: "Emas dengan emas, perak dengan perak, anggur dengan anggur, gandum dengan gandum, kurma dengan kurma, garam dengan garam harus sejenis dan harus sama serta dari tangan ke tangan (diberikan secara langsung melaui tangan)/kontan. M aka jika berbeda hal/barang/jenisnya maka silahkan saja asalkan dilakukan secara

${ }^{15}$ A bdul Aziz Dahlan, Ensiklopedi H ukum Islam, Jilid III, Jakarta: PT. Ichtiar Baru Van Hoeve, 1996), hlm. 1610

16 Muhammad Rawwal Qal'ahji, Ensiklopedi Figh U mar bin Khaththab ra, terj. M. A bdul Mujieb As, cet. ke-1 (Jakarta: PT. Raja Grafindo Persada, 1999), hlm. 49

${ }^{17}$ Abdul Aziz Dahlan, Ensiklopedi, III: 1610

18 Dahlan, Ensiklopedi, hlm. 1610

19 Muslim, Shahîh M uslim, hlm. 692. 
langsung (penyerahan dan penerimaannya memakai tangan secara langsung)".

Ribâ al-fadhl adalah tambahan kelebihan dari suatu pinjaman yang dibayar dengan suatu benda, yaitu pembayaran tambahan dari peminjaman pada yang memberikan pinjaman dalam pertukaran barang yang sejenis, seperti gandum ditukarkan dengan gandum, barley dengan barley atau anggur dengan anggur. Sedangkan menurut A hmad bin Abdurrazzaq dalam fatwanya tentang jual beli, ribâ al-fadhl adalah menjual suatu makanan takaran dengan makanan takaran sejenis dengan memberi tambahan pada salah satu, dan menjual barang timbangan dengan barang timbangan sejenis dengan adanya tambahan pada salah satunya, misalnya emas dengan emas, perak dengan perak, dengan tambahan pada salah satu.20 Semua perjanjian ini menurut Afzalurrahman mengandung unsur ribâ, karena itu Rasûlullâh SAW tidak membatasi ribâ sebatas transaksi pinjam-meminjam, tetapi dalam semua bentuk barter penjualan.21 Sebagaimana yang ditunjukkan dalam hadîts nabi sebagai berikut:

$$
\text { والبر بالبرربا الاهاء وهاء, والشعير بالشعيرربا الا هاء وهاء, والتمر بالتمر ربا الاهاء } 22
$$

Dari hadîts tersebut dapat dikatakan bahwa unsur ribâ terdapat di dalam tukar menukar barang dalam jenis yang sama dan dalam jumlah yang berbeda.

Mengutip pendapat al-Qardhawi,23 prinsip syara jual beli mata uang adalah harus kontan. Dengan demikian, bagaimana dengan transaksi jual beli mata uang yang dilakukan secara bertangguh, baik pada transaksi spot apalagi forward. Jika dianalisis secara seksama pada transaksi spot dan forward terdapat unsur ribâ, yaitu: (1) Unsur bunga, bunga diyakini secara pasti mengandung unsur ribâ dengan

20A hmad bin A bd al-Razzâq al-Duwaysy, Fatwa-Fatwa Jual B eli, terj. M. A bdul Ghoffar E.M., cet. ke-1 (Bogor: Pustaka Imam asy-Syafi'i, 2004), hlm. 271

21 Afzalurrahman, M uhammad sebagai Seorang Pedagang (M uhammad A s A Trader), terj. Dewi N urjulianti, Isnan, dkk. (Jakarta: Yayasan Swarna Bhumy, 1997), hlm. 313

22 Imâm al-Bukhârî, Shahîh al-Bukhârî, Juz II (Beirut: Dâr ibn Katsîr, 1990), hlm. 760.

23 Yusuf Qardhawi, Fatwa-F atwa Kontemporer, terj. As'ad Yasin (Jakarta: Gema Insani Press, 1996), hlm. 586. 
demikian bunga adalah ribâ; (2) penyerahan dana tidak dilakukan secara simultan tetapi bertangguh. Minimal selama 2 hari setelah tanggal transaksi pada transaksi spot dan 30, 90, 180 hari pada transaksi forward.

Dengan demikian, secara meyakinkan bahwa transaksi jual beli mata uang yang terjadi tidak sesuai dengan prinsip syara' dalam hadis nabi di atas, dengan demikian unsur ribâ terdapat dalam transaksi jual beli mata uang.

Kedua, maysîr. Tentang maysîr (judi) atau qimar (spekulasi), secara eksplisit, Allâh telah melarangnya. ${ }^{24}$ M aysîr menurut Afzalurrahman adalah memperoleh sesuatu dengan sangat mudah tanpa kerja atau mendapat keuntungan tanpa bekerja.25 Oleh sebab itu disebut berjudi (maysîr). Transaksi jual beli mata uang yang terjadi saat ini secara pasti menyatakan suatu perilaku bisnis yang sematamata mengharapkan keuntungan yang besar dengan tanpa bekerja dan berusaha.

Ketiga, gharâr. Ibnu Taimiyah mengatakan bahwa gharâr itu dilibatkan apabila seseorang tidak tahu apa yang tersimpan pada dirinya apa yang akan terjadi pada akhirnya sebuah kegiatan bisnis/ jual beli, dan setiap transaksi yang bersifat open ended mengandung unsur gharâr. Ada unsur resiko yang mengandung keraguan, probabilitas dan ketidakpastian secara dominan, juga unsur keraguan yang dikaitkan dengan penipuan atau kejahatan oleh salah satu pihak terhadap pihak lainnya. ${ }^{26}$

Diriwayatkan oleh Abd Allâh bin Umar, Sa'îd bin Musyayib, Abû Hurayrah dan Ibnu Abbâs, bahwa Rasûlullâh SAW melarang semua transaksi yang mengandung unsur gharâr. Para ahli bersepakat bahwa adanya gharâr dalam berbagai kontrak bisnis menjadikan transaksi tersebut cacat dan tidak valid dan mereka tidak sepakat terhadap masalah-masalah yang berkaitan dengan jumlah dan kualitas barang yang dapat menimbulkan gharâr.

Keempat, unsur Juhala. Transaksi jual beli mata uang mengandung unsur juhala sebagaimana unsur gharâr. Unsur ketidakpastian (juhala) juga sangat dominan, karena dasar

24 Lihat surat al-Baqarah ayat 219 dan suratal-M aidah ayat 90-91.

${ }_{25}$ A fzalurrahman, M uhammad, hlm. 313

26 Islahi, Konsepsi Ekonomi, hlm. 168. 
transaksinya ada kemungkinan kerugian atau keuntungan yang tidak dapat diramalkan dan dipastikan, dan unsur ketidakpastian tersebut dalam transaksi jual beli mata uang tidak dapat terhindari. Unsur juhala dalam transaksi mata uang terjadi jika kurs harga jual atau beli belum ditentukan pada saat akad berlangsung sehingga transaksi ini mengandung unsur juhala yang hal ini dilarang dalam bisnis Islam.

Dalam pelaksanaannya, jual beli mata uang harus memperhatikan beberapa batasan, yaitu: Pertama, nilai tukar yang diperjualbelikan dapat dikuasai langsung, baik oleh pembeli maupun penjual sebelum keduanya berpisah badan. Penguasaan itu bisa berbentuk penguasaan secara material dan hukum. Kedua, apabila mata uang yang diperjualbelikan itu dari jenis yang sama, maka harus dalam kualitas dan kuantitas yang sama, sekalipun modelnya berbeda. Ketiga, tidak berlaku hak khiyâr syarat dalam akad sharf, yaitu hak pilih bagi pembeli apakah akan melanjutkan jual beli atau tidak yang disyaratkan ketika berlangsung transaksi. Keempat, tidak terdapat tenggang waktu dalam akad karena penguasaan objek akad harus dilakukan secara tunai sebelum keduanya berpisah badan, oleh sebab itu, apabila salah satu pihak mensyaratkan tenggang waktu, maka akad ini tidak sah karena berarti terjadi penangguhan pemilihan dan penguasaan objek akad sharf. ${ }^{27}$

Dengan memperhatikan beberapa batasan tersebut, terdapat beberapa tingkah laku pedagang yang dewasa ini biasa dilakukan di pasar valuta asing konvensional harus dihindari, yaitu antara lain: (1) Pedagang tanpa penyerahan (future non-delivery trading atau margin trading); (2) Jual beli valas bukan transaksi komersial (arbitrage), baik spot maupun forward; (3) Melakukan penjualan melebihi jumlah yang dimiliki atau dibeli (over sold); dan (4) melakukan transaksi swap.28

\section{Para pihak yang Bertransaksi Jual Beli Mata Uang}

Para pihak yang melakukan transaksi jual beli mata uang secara umum telah memenuhi syarat untuk melakukan transaksi karena terdiri dari orang-orang yang profesional dan sangat mengerti dengan seluk beluk transaksi yang dilakukan dan kedua belah pihak

27 Dahlan, Ensiklopedi, hlm. 1611.

28 Muhammad Syafi'i Antonio, Bank Syariah: Dari Teori ke Praktik, cet. ke-1 (Jakarta: Gema Insani Press, 2001), hlm. 197. 
mempunyai wewenang untuk melakukan tindakan (dewasa dan sehat pikirannya). Para pihak ini harus melakukan transaksi atas kehendak sendiri, jika bukan karena kehendak sendiri atau ada paksaan lain, maka transaksi yang dilakukan tersebut tidak sah karena transaksi ini sangat memerlukan akal sehat dalam memutuskan apakah pembeli jadi atau tidak dalam melakukan transaksi dan para pihak ini pun bukanlah orang yang boros dalam melakukan transaksi. Semua pihak yang melakukan transaksi merupakan orang yang bisa mempertanggungjawabkan perbuatan yang dilakukan terhadap hukum yang berlaku.

Pihak-pihak yang melakukan transaksi jual beli mata uang haruslah dilakukan secara langsung dan kontan, kata langsung ini berarti bahwa para pihak (penjual dan pembeli) haruslah bertemu sehingga apabila kedua pihak yang melakukan transaksi tersebut tidak bertemu atau melakukan transaksi pertukaran mata uang tidak secara langsung maka jual beli tersebut tidak sah, sesuai hadîts nabi yang berbunyi:

$$
\begin{aligned}
& \text { لاتبيعو ا الذهب بالذهب الا مثلا بمثل ولاتشفو ا بعضها على بعض, ولاتبيعو الورق بالورق }
\end{aligned}
$$

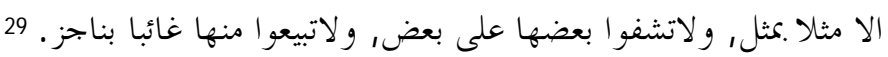

Artinya: "Janganlah kalian jual beli emas dengan emas kecuali yang sejenis, demikian juga daun kecuali sejenis, dan jangan jual beli sesuatu yang tersembunyi dengan sesuatu yang nampak".

Hadîts di atas sudah dengan jelas menerangkan bahwa transaksi jual beli mata uang haruslah dilakukan secara kontan dan langsung.

\section{Shighat Akad dalam Transaksi Jual Beli Mata Uang}

Tujuan pokok dari akad adalah untuk mengatur hubungan dan ikatan pergaulan manusia agar terdapat kelancaran hubungan dan kemaslahatan serta kemanfaatan dan tolong menolong antara anggota masyarakat dengan ketelitian pengaturan agar semuanya dapat berjalan dengan lancar.

Khusus dalam jual beli, tujuan akad adalah memindahkan barang dari penjual kepada pembeli dengan imbalan tertentu. Dalam

29 al-Bukhârî, Shahîh al-B u khârî, Jilid II, hlm. 761-762. 
bahasa arab kata akad diambil dari lafadz: عقد - يعقد - عقدا yang artinya ikatan. 30

Rukun akad adalah ijab dan qabûl. Ijab merupakan pernyataan oleh pihak pertama atau penjual mengenai penyerahan suatu barang, sedangkan qabûl berarti pernyataan yang dilakukan oleh pihak kedua atau pembeli tentang penerimaan suatu bidang. ljab dan qabûl disebut shighat al-aqdi atau pernyataan yang menunjukkan kesepakatan kedua belah pihak. Menurut Hasbi ash-Shhiddieqy, shighat al-aqdi mempunyai tiga syarat, yaitu: (1) Harus jelas pengertiannya; (2) harus sesuai antara ijab dan qabûl; (3) harus menggambarkan kesungguhan dari pihak-pihak yang bersangkutan. ${ }^{31}$

Shighat al-aqdi dapat dilakukan dengan berbagai macam cara, yaitu: (1) Secara lisan, yaitu dengan menggunakan bahasa atau perkataan apa pun asal dapat dimengerti oleh masing-masing pihak yang berakad; (2) dengan tulisan, yaitu suatu akad yang dilakukan dengan tulisan oleh salah satu pihak atau kedua pihak yang berakad. Cara yang demikian ini dilakukan apabila orang yang berakad tidak berada dalam satu majelis atau orang yang berakad salah satu atau keduanya tidak dapat berbicara; (3) dengan isyarat, yaitu suatu akad yang dilakukan dengan bahasa isyarat yang dapat dipahami oleh kedua belah pihak yang berakad. Cara yang demikian ini dapat dilakukan apabila salah satu atau kedua belah pihak yang berakad tidak dapat berbicara atau bisa dan tidak dapat menulis.32

Para fuqahâ' bersepakat tentang ijab dan qabûl dalam transaksi jual beli mata uang harus dilakukan dari tangan ke tangan (tunai), Rasûlullâh SAW bersabda tentang hal ini dalam hadîts yang berbunyi:

$$
\begin{aligned}
& \text { لاتبيعو ا الذهب بالذهب الا مثلا مثثل ولاتشفوا بعضها على بعض, ولاتبيعو الورق بالورق } \\
& 33 \\
& \text { الا مثلا بمثل, و لاتشفو ا بعضها على بعض, ولاتبيعو ا منها غائبا بناجز . }
\end{aligned}
$$

30 Ahmad Warson Munawir, Kamus al-M unawir A rab Indonesia (Surabaya: Pustaka Progresif, 1997), hlm. 953

31 Hasbi ash-Shiddieqy, Pengantar Fiqh Muamalah (Semarang: Pustaka Rizqi Putra, 2001), hlm. 29

32 A hmad Azhar Basyir, A sas-A sas Hukum Muamalah (Yogyakarta: UII Press, 2000), hlm. 69

33 al-Bukhârî, Shahîh al-B ukhârî, Jilid II, hlm. 761-762 
Hadîts di atas telah menerangkan tentang akad yang harus dilakukan secara tunai dan tidak boleh ditangguhkan karena hal itu akan menjurus kepada hal yang diharamkan yaitu ribâ.

Penafsiran para ahli tentang jual beli mata uang yaitu bertujuan agar tidak ada pihak-pihak yang dirugikan dan dizalimi, dan tidak mendatangkan madarat bagi masyarakat banyak. Persoalan uang merupakan masalah yang berkaitan dengan hajat orang banyak terhadap keutuhan ekonomi, oleh sebab itu dapat dimengerti pemahaman sebaliknya dari hikmah yang terkandung dari ketentuan diatas. Di satu sisi pertukaran dan perdagangan uang merupakan suatu kebutuhan untuk perdagangan internasional dan kegiatan ekonomi yang berhubungan dengan negara lain, tetapi di sisi lain, harus dapat menghindari hal-hal yang dilarang syari'ah dan perilaku yang mendatangkan kemadaratan.

A kan tetapi ijab dan qabûl (serah terima) dalam transaksi jual beli mata uang modern saat ini terjadi tidak secara berhadap-hadapan langsung antara penjual dan pembeli. Tetapi melalui seperangkat alat komunikasi canggih seperti komputer, telepon, telex, facsimile dan dilakukan dalam ruangan yang disebut dealing room. Bahasa yang digunakan adalah bahasa yang sangat simple dalam isyarat-isyarat tertentu, tetapi tentunya sangat dipahami oleh masing-masing pihak. Pada transaksi yang umum terjadi ijab qabul yang tidak diikuti dengan serah terima uang yang dijualbelikan atau tidak dilakukan secara cash dan carry, baik pada transaksi spot, forward, dan margin trading. Tetapi dilakukan secara bertanggung dan mata uang yang diperjualbelikan tidak ada secara riil, melainkan sebatas nominal sejumlah transaksi yang dilakukan yang telah disepakati penyerahan dananya ditransfer lewat rekening masing-masing. Dalam kesepakatan yang dilakukan sebelum transaksi disetujui kedua belah pihak masing-masing telah menjelaskan secara detail tentang harga, jumlah (nilai) transaksi dan cara pembayaran.

$\mathrm{Hal}$ ini sesuai dengan kaidah fiqhiyyah, "al-musyaqqah tajlib altaysîr" (kesulitan itu menarik kemudahan). ${ }^{34}$ Oleh sebab itu, menghadirkan fisik mata uang yang jumlahnya milyaran dolar akan menimbulkan kesulitan bagi kedua belah pihak. Dengan demikian

34 Abd al-Wahab Khallâf, Ilmu U shulul Fiqh, terj. Masdar Helmy (Jakarta: Gema Risalah Press, 1997), hlm. 372. 
berdasarkan kaidah hukum Islam tersebut maka transaksi jual beli mata uang tanpa menghadirkan objeknya di majelis akad adalah dibenarkan untuk menghindari kesulitan, tetapi kesulitan yang dimaksud tetap pada porsinya, hanya sebatas yang tidak memungkinkan.

Persoalan jual beli mata uang telah menjadi sangat populer, umum, dan hampir dilakukan serta diterima sebagai suatu transaksi yang dipraktekkan di seluruh dunia. Tidak ada sistem perekonomian suatu negara mengalami kemajuan tanpa berhubungan dengan jual beli mata uang, oleh sebab itu selayaknya jual beli mata uang diterima dan diadopsi sebagai kebutuhan di bidang ekonomi, dan bermanfaat serta sulit sekali dipisahkan dari industri modern. Tetapi jika jual beli mata uang tersebut dilakukan dengan tujuan untuk spekulasi, dan merusak sistem perekonomian suatu negara, maka hal inilah yang sangat bertentangan dengan tujuan syari'ah. Solusi yang paling baik yang harus dilakukan menurut penyusun adalah mengadopsi dan menyesuaikan sistem jual beli mata uang yang ada sekarang, dengan prinsip-prinsip syari'ah, dan penyusun sepakat dengan pendapat Qardhawi dan Imam Malik bahwa batasan kontan dan tangguh harus diserahkan kepada kebiasaan masyarakat. Ini berdasarkan kaidah fighiyah bahwa "adat kebiasaan dapat menjadi hukum" (al-adat muhakkamah).

Agama Islam bukan berarti melarang umatnya mencari keuntungan atau laba, keuntungan yang diperbolehkan dalam Islam adalah laba yang diperoleh secara wajar, tidak merugikan dan mengurangi hak-hak bagi kedua belah pihak yang melakukan transaksi jual beli. Ekonomi Islam tidak hanya memfokuskan pada keuntungan materi atau duniawi semata, tetapi juga keuntungan ukhrawi. Allah SWT menegaskan dalam firman-Nya.

$$
\text { من كان يريد حرث الأخرة نزدله في حرثه ومن كان يريد حرث الدنيا نؤته منها وماله في } 35 \text { من }
$$

Artinya: “Barang siapa menginginkan bagian pada kehidupan akhirat maka kami akan menambah bagiannya, dan barang siapa menginginkan bagian di kehidupan dunia maka kami akan memberikannya dan tidak bagian baginya di akhirat".

35 A s-Syura (42): 20 
Berdasarkan ayat diatas, maka sebagai masyarakat muslim sudah seharusnya didalam melakukan jual beli tidak hanya mengejar keuntungan duniawi semata, tetapi juga keuntungan ukhrawi, yaitu bertindak jujur dan amanah.

Muhammad Nejatullah Siddiqi menjelaskan bahwa dalam hukum Islam aktivitas ekonomi dan tujuannya dianggap suatu kaidah atau suatu cara untuk mencapai kehidupan. Keselarasan ekonomi harus diselaraskan dengan tujuan akhir, yaitu mendapatkan falâh atau mencapai kesempurnaan dunia dan akhirat. Prinsip ekonomi dalam Islam bertujuan untuk mengembangkan kebajikan semua pihak sebagai mana dinyatakan dalam konsep falâh yang terdapat dalam al-Qur'an. Prinsip ini mengandung prinsip ekonomi dengan nilai secara langsung. Untuk mencapai falâh, aktivitas ekonomi harus mengandung dasar-dasar moral. dalam membuat keputusan ekonomi, nilai etika sepatutnya dijadikan norma. ${ }^{36}$

Abdul Mannan juga menerangkan bahwa prinsip dasar yang telah ditetapkan dalam Islam mengenai perdagangan dan niaga adalah tolak ukur dari kejujuran, kepercayaan dan ketulusan. 37

Tidak dipungkiri bahwa kekayaan materi merupakan bagian penting dalam falâh. Bahaya kelaparan, sulitnya mendapatkan kebutuhan hidup dan faktor-faktor yang lain mengganggu tubuh dan pikiran tentu tidak memungkinkan suasana yang menyenangkan untuk mencapai tujuan hidup di dunia. Tapi hal ini tidak berarti bahwa manusia bebas dalam berkarya dengan meninggalkan norma dan etika serta kaidah yang ada.

\section{Penutup}

Setelah melakukan pembahasan mengenai transaksi jual beli mata uang menurut perspektif hukum Islam, maka penyusun menyimpulkan bahwa transaksi jual beli mata uang merupakan salah satu kegiatan bisnis yang penting dalam perputaran roda perekonomian dunia, sehingga transaksi jual beli mata uang ini sangatlah dibutuhkan bagi kelancaran perdagangan dunia. Transaksi jual beli mata uang dalam Islam dikenal dengan istilah al-sharf dan hal

36Muhammad Nejatullah Siddiqi, Kegiatan Ekonomi dalam Islam, terj. Anas Sidik (Jakarta: Bumi A ksara, 1991), hlm. 5

37 Mannan, T eori dan Praktek, hlm. 288. 
ini diperbolehkan dalam Islam. Hanya saja transaksi jual beli mata uang yang terjadi saat ini banyak dimasuki oleh unsur-unsur yang dilarang dalam bisnis Islam, seperti gharâr, maysîr, ribâ, dan juhala di mana unsur-unsur tersebut sangat merugikan salah satu pihak.

\section{D aftar Pustaka}

Afzalurrahman, M uhammad Sebagai Seorang Pedagang (M uhammad as A Trader), terj. Dewi Nurjulianti, Isnan dkk. Jakarta: Yayasan Swarna Bhumy, 1997.

Antonio, Muhammad Syafi'i. Bank Syariah: Dari Teori Ke Praktik, cet. ke-1. Jakarta: Gema Insani Press, 2001.

Ash-Shiddieqy, Hasbi Pengantar Figh M uamalah. Semarang: Pustaka Rizqi Putra, 2001.

Basyir, Ahmad Azhar. A sas-A sas Hukum M uamalah. Yogyakarta: UII Press, 2000.

Bukhârî, Imâm al-. Shahîh al-Bukhârî . Beirut: Dâr ibn Katsîr, 1990

Dahlan, Abdul Aziz. Ensiklopedi Hukum Islam, cet. ke- 1. Jakarta: PT. Ichtiar Baru Van Hoeve, 1996.

Darmawan, Indra. Pengantar U ang dan Perbankan, cet. 1. Jakarta: Rineka Cipta, 1992.

Duwaisy, A hmad bin A bd al-Razzâq al-. Fatwa-Fatwa Jual Beli, terj. M. A bdul Ghoffar E.M., cet. ke-1. Bogor: Pustaka Imam asy-Syafi'i, 2004.

Fatchurrahman, Mukhtar Yahya. Dasar-D asar Pembinaan Hukum Fiqh Islam, cet. ke-1, Bandung: al-Ma'arif, 1986.

Islahi, A.A. Konsepsi Ekonomi Ibnu Taimiyah, terj. Anshari Thayib. Surabaya: Bina IImu, 1997.

Karim, Adiwarna A. Ekonomi Islam Suatu Kajian Kontemporer, cet. ke-1. Jakarta: Gema Insani Press, 2001. 
Khallaf, A bdul Wahab. IImu U shulul Fiqh, terj. Masdar Helmy. Jakarta: Gema Risalah Press, 1997.

Mâjah, Ibn. Sunan Ibn M âjah. Beirut: Dâr al-Fikr, t.t.

Manan, M. Abdul. Teori dan Praktek Ekonomi Islam, terj. M. Nastangin Yogyakarta: PT. Dana Bhakti Wakaf, 1995.

Mannan, Abdul. Teori dan Praktek Ekonomi Islam, terj. M. Nastangin. Yogyakarta: PT. Dana Bhakti Wakaf, 1997.

Munawir, Ahmad Warson. Kamus al-M unawir Arab Indonesia. Surabaya: Pustaka Progresif, 1997.

Muslim, Imam. Shahhihh M uslim, . ttp.: A I-Qana'ah, t.t.

Nabhani, Taqiyuddin An. M embangun Sistem Ekonomi Alternatif Perspektif Islam, alih bahasa Maghruf Wachid, Surabaya: Risalah Gusti, 1996.

Qal'ahji, Muhammad Rawwal. Ensiklopedi Fiqh U mar bin Khaththab ra,, penerjemah M. Abdul Mujieb As, cet. ke-1, Jakarta: PT. Raja Grafindo Persada, 1999.

Qardhawi, Yusuf. Fatwa-Fatwa Kontemporer, terj. As'ad Yasin. Jakarta: Gema Insani Press, 1996.

Shiddiqi, Muhammad Nejatullah. Kegiatan Ekonomi Dalam Islam, terj. Anas Sidik , Jakarta: Bumi A ksara, 1991.

Sinungan, Muchdarsyah. U ang dan Bank, cet. ke-3. Jakarta: Rineka Cipta, 1991.

Utomo, Setiawan Budi. Fiqih Aktual, Jawaban Tuntas Masalah Kontemporer, cet. ke-1, Jakarta: Gema Insani Press, 2003. 